\title{
A Research on Determination of Some Properties of Butter Made from Creams Extracted from Whey and Milk
}

\author{
Asya Çetinkaya
}

\section{ABSTRACT}

In this study, it was aimed to determine the effect of some production parameters on the characteristics of butters made from whey, which is an important dairy by-product, and creams obtained from milk.

The acidity values of milk, whey, cream, and butter were respectively detected as $\quad 0.17 \pm 0.00 \%, \quad 0.13 \pm 0.01 \%, \quad 0.22 \pm 0.01 \%, \quad 0.24 \pm 0.01 \%$, $0.26 \pm 0.00 \%, \quad 0.25 \pm 0.01 \%$, fat values were respectively detected as; $3.50 \pm 0.14 \%, \quad 0.60 \pm 0.19 \%, \quad 39.0 \pm 0.34 \%, \quad 43.0 \pm 0.35 \%, \quad 80.0 \pm 0.46 \%$, $84.0 \pm 0.42 \%$ and protein values were respectively detected as; $3.30 \pm 0.19 \%$, $0.68 \pm 0.03 \%, \quad 0.93 \pm 0.12 \%, \quad 0.54 \pm 0.03 \%, \quad 0.51 \pm 0.02 \%, \quad 0.58 \pm 0.00 \% . \quad 10$ saturated and 7 unsaturated fatty acids were detected in cream and whey butter samples. It was seen that the most common fatty acids were palmitic, stearic, myristic and oleic acid, and the amount of oleic, stearic and linoleic acid was higher in whey butter.

In conclusion, we can state that whey, which is an important dairy residue, can be used as an alternative raw material in butter production.

Keywords: butter, chemical properties, fatty acid components, whey.
Submitted : June 07, 2021

Published : July 11, 2021

ISSN: $2684-1827$

DOI: 10.24018 /ejfood.2021.3.4.321

\section{A. Çetinkaya*}

Kafkas University, Faculty of Engineering and Architecture, Department of Food Engineering, 36100, Kars, Turkey.

(e-mail: a_cetinkaya36@hotmail.com)

*Corresponding Author

\section{INTRODUCTION}

Milk fat is a component that plays a role in the physical characteristics, taste, aroma and nutritional value of dairy products. In addition to being a good source of energy in terms of nutritional physiology, it is also of great importance because it has its medium chain fatty acids, essential unsaturated fatty acids such as linoleic and arachidonic acid, fat-soluble vitamins A, D, E, K, and especially conjugated linoleic acid (CLA) in its composition [1].

The fatty acid composition of milk not only has an effect on the physical characteristics, oxidative stability and organoleptic quality of dairy products, but it also has positive effects on human health [2]. Butter is a dairy product that is physically obtained from milk, cream, yogurt, or by-products (whey, buttermilk, etc.) and does not contain any fat other than milk fat [3]. Butter is a dairy product that contains milk fat, which is the most important component of milk, and is an important dairy product in terms of its economic as well as nutritional value [4].

In addition, according to the Communiqué No. 2005/19 of the Turkish Food Codex, butter is a dairy product that should have a minimum of $80 \%$ and a maximum of $90 \%$ milk fat, a maximum of $2 \%$ non-fat milk dry matter and a maximum of $16 \%$ water content in its total weight [5].

In the composition of butter, in addition to low and high molecular fatty acids, monoenoic and polyenoic unsaturated fatty acids, butyric, capronic and caprylic acids from 4-6-8 carbon saturated fatty acids and unsaturated acids, palmitoolein, oleic and linoleic acids are in liquid state at room temperature and other fatty acids are in solid state. The unique fatty acid composition and low melting point of milk fat, which constitutes the structure of butter, plays a role in easier digestion of milk fat [6]. Since it is in the liquid state when secreted and available for digestion, butter is easier to digest and has a higher physiological value compared to other fats. In addition, the fact that butter contains fatty acids such as butyric acid, which is not found in any other fat, causes it to have a popular aroma [7].

The world population is increasing day by day, which necessitates that the basic needs of human beings are produced at a sufficient and qualified level. During the processing of milk, which is among important nutrition products, with various products, a significant part of the nutrients in milk passes on to some by-products such as skim milk, buttermilk, whey, boiled water identified as milk residues. The vast majority of the dairy industry residues is composed of residues resulting from butter and cheese production [8]. Whey is one of the most important byproducts of dairy technology. Its composition and properties vary according to the type and quality of the used milk and type of produced cheese [9].

In general, the yellowish-green liquid that remains at the end of the process of processing milk to cheese is called whey. The amount of obtained whey is approximately as $85 \%$ of the milk used in cheese production [10].

According to the data of the Turkish Statistical Institute (TÜIK) from the year 2018, total raw milk production in

Turkey is 22.120 .516 tons. Considering that $34.05 \%$ of the raw milk produced in a year is processed into cheese, it can be stated that approximately 753.230 tons of milk is used in cheese making and around 640. 245 tons of whey is obtained [11].

Utilization of whey, which contains about half of the milk dry matter is important both in terms of preventing environmental pollution and the value it contributes to the 
economy [12]. Besides the nutritional properties of whey due to its composition, its positive effects on health have been scientifically proven. Today, with the increasing tendency of consumers towards functional foods, the use of whey proteins as additives to various foods has become more widespread. In cheese production centers, the rate of fat in whey released during cheese making differs depending on the technology applied [8]. Nutrient-rich whey has many areas of usage. While creams extracted from whey can be used to standardize milk fat before cheese making, whey can also be used to make butter [13].

By using cream separators, whey can be separated until $0.05 \%$ fat is left. The cream obtained in this way can be transformed into butter after heat treatment and acidification with or without adding culture [14].

Free fatty acids (FFAs) are important precursors of catabolic reactions that produce volatile and aromacontributing compounds [15]. The amount of free fatty acids in dairy products not only has an important effect on the taste and structure of dairy products, but they also have potential effects on nutrition and health as antimicrobial agents [16]. Free fatty acids have strong sensory properties and are important compounds in the formation of flavor and aroma of many dairy products, especially cheese and fermented milk products [17], [18]. Free fatty acids also contribute to texture and functionality as they affect the surface tension and foaming capacity of milk [19], [20].

In this study, it was aimed to determine the effect of some production parameters on the qualities of butter produced from creams extracted from whey and milk.

\section{Methodology}

\section{A. Materials}

\section{Milk and whey}

Raw cow's milk and whey (separated from kashar cheese produced from cow's milk (Fig. 1) were obtained from the dairy factory producing cheese in the industrial zone between November 2019 and December 2019. The samples were brought to Kafkas University Faculty of Engineering and Architecture Food Engineering Laboratory, and after some samples were taken for a few physical analyses, they were processed in cream.

\section{Separator and churner}

The Alfa-Laval brand cream separator was used for the separation of raw milk and whey and Minisan brand smallsized churner was used for the churning of creams.

\section{Starter Culture}

CHN 11 and CHN 22 DVS (Chr. Hansen) coded mesophilic butter culture was used.

\section{B. Methods}

Butter production was carried out in three repetitions.

\section{Butter production in laboratory conditions. Production of cream butter}

Cream with $43 \%$ fat obtained by passing raw milk through separator was pasteurized by applying heat at $90{ }^{\circ} \mathrm{C}$ for 5 minutes. $2 \%$ mesophilic butter starter culture (Chr.
Hansen CHN 11 and CHN 22) was added to the cream and it was matured till $5.0-5.2 \mathrm{pH}$ at $25^{\circ} \mathrm{C}$. Then, it was cooled to the churning temperature, and churning process was done at $8-10{ }^{\circ} \mathrm{C}$. After the churning process was completed, buttermilk was emptied out and the processes of washing and malaxing were performed. Butter taken from the churner was placed in sterile 250-gram light-proof jars and stored at $4 \pm 1{ }^{\circ} \mathrm{C}$ for 2 days in the refrigerator, then chemical analyses and fatty acid analyses were performed.

\section{Butter production from creams obtained from whey}

During the production of cheddar cheese (Fig. 1), whey, which is separated during the extraction of the clot, is pasteurized by applying heat for 5 minutes at $90{ }^{\circ} \mathrm{C}$ after passing through the cream separator and $2 \%$ mesophilic butter starter culture (Chr. Hansen CHN 11 and CHN 22) was added to the cream and it was matured till $5.0-5.2 \mathrm{pH}$ at $25{ }^{\circ} \mathrm{C}$. Then, it was cooled to the churning temperature, and churning process was done at $8-10{ }^{\circ} \mathrm{C}$. After the churning process was completed, buttermilk was taken out and the processes of washing and malaxing were performed. Butter taken from the churner was placed in sterile 250-gram lightproof jars and stored at $4 \pm 1{ }^{\circ} \mathrm{C}$ for 2 days in the refrigerator, then chemical analyses and fatty acid analyses were performed.

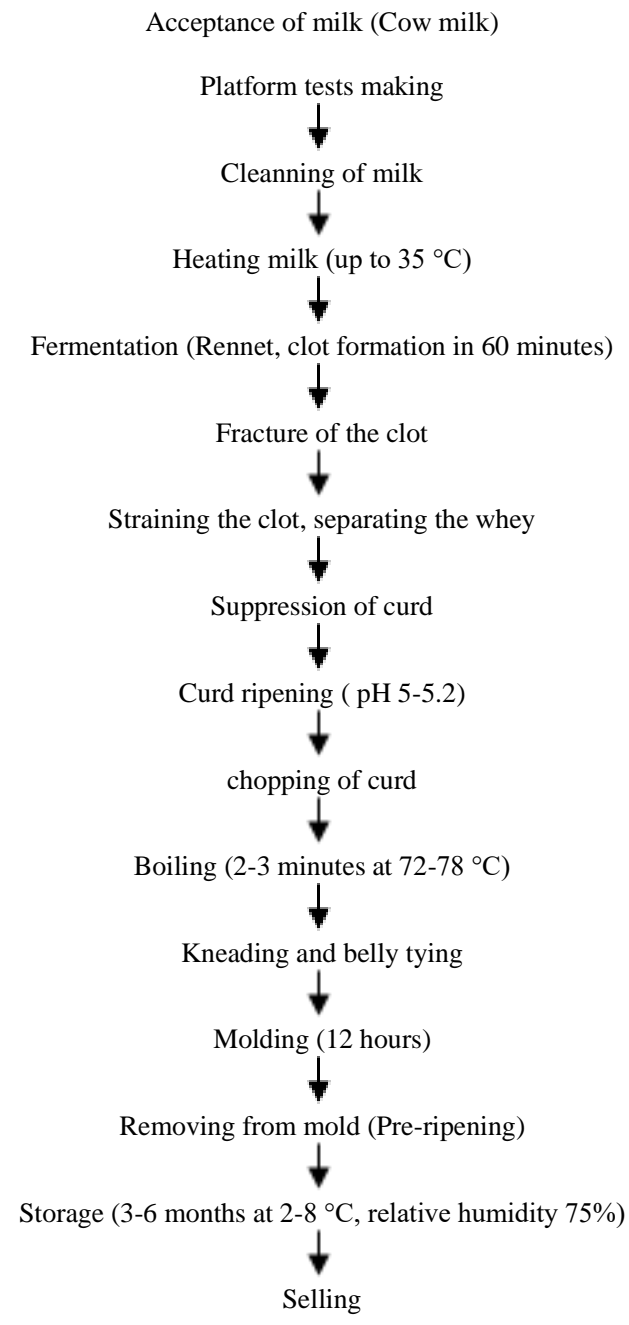

Fig. 1. Kashar cheese production flow chart.

\section{Chemical Analyses}

The fat contents of raw milk, whey, cream, and butter were detected by the Gerber method [21]-[23] and the 
acidity was detected by titration method and the results were stated in \% lactic acid [23], [24]. Protein determination in samples was determined by the Kjeldahl method [25]. Protein content was calculated by multiplying the total nitrogen amount by factor of 6.38 .

\section{Determination of fatty acid composition}

Fatty acid composition of the examples was determined according to the fatty acid methyl ester method (FAME) (AOAC 996.01) [26]. According to the method, approximately $0.1 \mathrm{~g}$ of fat, which was taken from fat samples obtained as a result of the lipid assay in line with Gerber method, was rinsed with $10 \mathrm{~mL}$ of $\mathrm{n}$-hexane and remixed with $0.5 \mathrm{~mL}$ of $2 \mathrm{~N}$ methanolic potassium hydroxide solution. After having been kept in a dark environment for 1-2 hours, $1 \mu \mathrm{l}$ was taken from the supernatant and directly injected into the gas chromatograph.

\section{GC Conditions for fatty acid composition analysis}

FAME composition in fat was analyzed by using Restek RTX-2330 capillary column (60 m, $0.25 \mathrm{~mm}$ i.d.0.1 $\mu \mathrm{m}$ film thickness, Bellefonte, PA, USA) and flame ionization detector (FID) in a Shimadzu brand gas chromatograph (model QP2010 Plus). The device was given $1 \mu \mathrm{L}$ of injection volume from the sample. Column furnace temperature was increased to $240{ }^{\circ} \mathrm{C}$ with $4{ }^{\circ} \mathrm{C}$ min- 1 increase after being kept for $3 \mathrm{~min}$ at $100{ }^{\circ} \mathrm{C}$ and was programmed to wait $18 \mathrm{mins}$ at the final temperature. The injection temperature was set to $250{ }^{\circ} \mathrm{C}$ and the detector temperature to $255^{\circ} \mathrm{C}$. Helium was used as carrier gas in the device. Injection split ratio was used at 1:80 ratio. To control the GC/FID system, LabSolution computer program was used and FAME mix 37 standard (Restek) as standard. FAME peaks were specified by comparing the chain lengths and retention times of the fatty acids specified in FAME standard.

\section{Statistical Analyses}

In the evaluation of the obtained results, the mean value and standard deviation of the samples were determined by using the SPSS package program and the differences between the samples were examined by the Duncan test.

\section{RESULTS AND DISCUSSION}

\section{A. Study Results}

The results of fat, protein and titration acidity of cow's milk, whey, cream, and butter are presented in Table I.

The fatty acids composition belongs to the cream and whey butter samples is given in Table II and Table III.

TABLE I: RESULTS OF CHEMICAL ANALYSIS OF MILK, WHEY, CREAM AND BUTTER USED IN BUTTER PRODUCTION
\begin{tabular}{ccccccc} 
Characteristic & Milk & Whey & $\begin{array}{c}\text { Whey } \\
\text { cream }\end{array}$ & $\begin{array}{c}\text { Milk } \\
\text { cream }\end{array}$ & Whey butter & Cream butter \\
\hline $\begin{array}{c}\text { Titration acidity } \\
\text { (\% l.a) }\end{array}$ & $0.17 \pm 0.00$ & $0.13 \pm 0.01$ & $0.22 \pm 0.01$ & $0.26 \pm 0.00$ & $0.26 \pm 0.00$ & $0.25 \pm 0.01$ \\
Fat & $3.50 \pm 0.14$ & $0.60 \pm 0.19$ & $39.0 \pm 0.34$ & $43.0 \pm 0.35$ & $80.0 \pm 0.46$ & $84.0 \pm 0.42$ \\
Protein & $3.30 \pm 0.19$ & $0.68 \pm 0.03$ & $0.93 \pm 0.12$ & $0.54 \pm 0.03$ & $0.51 \pm 0.02$ & $0.58 \pm 0.00$ \\
\hline
\end{tabular}

TABLE II: FATTY ACID CONTENT OF CREAM A|ND BUTTER MADE From MiLK AND WHEY (\%)

\begin{tabular}{|c|c|c|c|c|c|c|c|}
\hline \multirow{2}{*}{ Fatty Acids } & \multicolumn{7}{|c|}{ Samples $\left(\boldsymbol{X}_{ \pm} S_{x}\right)$} \\
\hline & $\mathrm{n}$ & 1 & 2 & 3 & 4 & F value & $\mathrm{p}$ \\
\hline \multicolumn{8}{|c|}{ Satured fatty acid } \\
\hline C4:0 butyric & 3 & $2.05 \pm 0.12$ & $2.06 \pm 0.05$ & $2.15 \pm 0.08$ & $2.12 \pm 0.09$ & 1.09 & $>0.05$ \\
\hline C6:0 Caproic & 3 & $1.30 \pm 0.08 \mathrm{~b}$ & $1.40 \pm 0.02 \mathrm{ab}$ & $1.44 \pm 0.05 \mathrm{a}$ & $1.50 \pm 0.13 \mathrm{a}$ & 4.66 & 0.05 \\
\hline C8:0 Caprylic & 3 & $0.64 \pm 0.05 \mathrm{c}$ & $0.87 \pm 0.01 \mathrm{ab}$ & $0.83 \pm 0.02 b$ & $0.96 \pm 0.14 \mathrm{a}$ & 12.46 & 0.001 \\
\hline C10:0 Capric & 3 & $1.58 \pm 0.07 b$ & $1.98 \pm 0.01 \mathrm{a}$ & $1.95 \pm 0.01 \mathrm{a}$ & $2.25 \pm 0.42 \mathrm{a}$ & 7.08 & 0.001 \\
\hline C12:0 Lauric & 3 & $2.05 \pm 0.04 \mathrm{c}$ & $2.60 \pm 0.03 \mathrm{ab}$ & $2.44 \pm 0.03 \mathrm{bc}$ & $3.02 \pm 0.59 \mathrm{a}$ & 7.39 & 0.01 \\
\hline C14:0 Myristic & 3 & $9.70 \pm 0.16 \mathrm{c}$ & $10.91 \pm 0.05 b$ & $10.81 \pm 0.15 b$ & $12.03 \pm 1.07 \mathrm{a}$ & 11.92 & 0.001 \\
\hline $\begin{array}{c}\text { C15:0 } \\
\text { Pentadecanoic }\end{array}$ & 3 & $1.24 \pm 0.02 \mathrm{~b}$ & $1.62 \pm 0.01 \mathrm{a}$ & $1.61 \pm 0.03 \mathrm{a}$ & $1.44 \pm 0.25 \mathrm{a}$ & 8.16 & 0.01 \\
\hline C16:0 Palmitic & 3 & $32.93 \pm 0.13 b$ & $35.49 \pm 0.03 \mathrm{a}$ & $33.52 \pm 0.38 b$ & $34.76 \pm 1.05 \mathrm{~b}$ & 16.97 & 0.001 \\
\hline $\begin{array}{c}\text { C17:0 } \\
\text { Heptadecanoic }\end{array}$ & 3 & $0.93 \pm 0.01 \mathrm{a}$ & $0.95 \pm 0.01 \mathrm{a}$ & $0.92 \pm 0.21 \mathrm{a}$ & $0.77 \pm 0.16 \mathrm{~b}$ & 3.65 & 0.05 \\
\hline C18:0 Stearic & 3 & $13.75 \pm 0.34 \mathrm{a}$ & $12.70 \pm 0.01 b$ & $12.00 \pm 0.33 \mathrm{c}$ & $11.22 \pm 0.49 \mathrm{c}$ & 24.50 & 0.001 \\
\hline \multicolumn{8}{|c|}{ Unsaturated fatty acids } \\
\hline C14:1 Myristoleic & 3 & $0.69 \pm 0.01 \mathrm{c}$ & $0.80 \pm 0.01 b$ & $0.88 \pm 0.02 \mathrm{a}$ & $0.81 \pm 0.03 \mathrm{a}$ & 51.49 & 0.001 \\
\hline C16:1 palmitoleic & 3 & $2.01 \pm 0.09$ & $1.98 \pm 0.01$ & $2.07 \pm 0.05$ & $1.90 \pm 0.25$ & 0.85 & $>0.05$ \\
\hline C18:1 n9c oleic & 3 & $27.56 \pm 0.56 \mathrm{a}$ & $24.60 \pm 0.02 \mathrm{c}$ & $26.32 \pm 0.45 b$ & $24.42 \pm 1.10 \mathrm{c}$ & 22.08 & 0.001 \\
\hline C18:1 Elaidic & 3 & $0.57 \pm 0.04$ & $0.59 \pm 0.03$ & $0.56 \pm 0.03$ & $0.42 \pm 0.03$ & 1.09 & $>0.05$ \\
\hline C18:2n6c linoleic & 3 & $2.13 \pm 0.17 \mathrm{a}$ & $1.53 \pm 0.02 b$ & $1.64 \pm 0.22 b$ & $1.51 \pm 0.35 b$ & 5.99 & 0.01 \\
\hline $\begin{array}{l}\text { C20:1 cis-11- } \\
\text { Eicosenoic }\end{array}$ & 3 & $0.46 \pm 0.04$ & $0.45 \pm 0.01$ & $0.48 \pm 0.03$ & $0.36 \pm 0.13$ & 1.04 & $>0.05$ \\
\hline $\begin{array}{c}\text { C20:2 cis- } \\
\text { 11,14,Eicosadienoic }\end{array}$ & 3 & $0.63 \pm 0.18 \mathrm{a}$ & $0.18 \pm 0.01 \mathrm{c}$ & $0.38 \pm 0.09 \mathrm{~b}$ & $0.54 \pm 0.05 \mathrm{ab}$ & 13.85 & 0.001 \\
\hline
\end{tabular}

* Values given are three repeats averages.

Results are expressed as mean \pm standard deviation of means.

*** a,b,c : Different letters in the same line refers significant differences between the averages $(\mathrm{p}<0.001, \mathrm{p}<0.01, \mathrm{p}<0.05)$.

1: whey cream 2: milk cream, 3: whey butter, 4 : milk cream butter. 
TABLE III: FATTY ACID CONTENT OF CREAM AND BUTTER MADE FROM MiLK AND WHEY (\%)

\begin{tabular}{ccccccc}
\hline \multirow{2}{*}{ Fatty acids } & $\mathrm{n}$ & \multicolumn{5}{c}{ Samples * } \\
\cline { 3 - 7 } & & 1 & 2 & 3 & 4 & $\mathrm{p}$ \\
\hline$\Sigma$ SFA & 3 & $66.12 \pm 1.00$ & $70.54 \pm 0.18$ & $67.67 \pm 1.10$ & $70.07 \pm 1.35$ & 0.05 \\
$\Sigma$ UNSFA & 3 & $33.39 \pm 1.06$ & $29.58 \pm 0.54$ & $32.33 \pm 0.86$ & $29.93 \pm 1.54$ & 0.01 \\
SCFA & 3 & $3.34 \pm 0.21 \mathrm{c}$ & $3.44 \pm 0.03 \mathrm{~b}$ & $3.59 \pm 012 \mathrm{a}$ & $3.61 \pm 0.21 \mathrm{a}$ & 0.05 \\
MCFA & 3 & $15.87 \pm 0.35 \mathrm{c}$ & $18.78 \pm 0.13 \mathrm{~b}$ & $18.54 \pm 0.27 \mathrm{~b}$ & $21.56 \pm 0.49 \mathrm{a}$ & 0.01 \\
LCFA & 3 & $79.86 \pm 1.24 \mathrm{a}$ & $77.32 \pm 0.16 \mathrm{~b}$ & $77.04 \pm 0.54 \mathrm{~b}$ & $74.74 \pm 0.81 \mathrm{c}$ & 0.01 \\
VLCFA & 3 & $1.09 \pm 0.21 \mathrm{a}$ & $0.60 \pm 0.03 \mathrm{c}$ & $0.86 \pm 0.12 \mathrm{~b}$ & $0.91 \pm 0.19 \mathrm{a}$ & 0.05 \\
$\Sigma$ MUFA & 3 & $31.26 \pm 0.70 \mathrm{a}$ & $27.89 \pm 0.38 \mathrm{c}$ & $30.31 \pm 0.41 \mathrm{a}$ & $27.91 \pm 1.21 \mathrm{~b}$ & 0.01 \\
$\Sigma$ PUFA & 3 & $2.75 \pm 0.35 \mathrm{a}$ & $1.69 \pm 0.02 \mathrm{c}$ & $2.03 \pm 0.30 \mathrm{~b}$ & $2.02 \pm 0.38 \mathrm{~b}$ & 0.05 \\
\hline
\end{tabular}

Abbreviations: Saturated fatty acids (SFAs), Unsaturated fatty acids (UNSFA), Short-chain fatty acids (SCFA), Medium-chain fatty acids (MCFA), Longchain fatty acids (LCFA).

Very long chain fatty acids (VLCFA), Monounsaturated fatty acid (MUFA), Polyunsaturated fatty acid (PUFA).

\section{B. Discussion}

The fat values of cow's milk were lower than those determined by [7] and [27] in the milk used in butter production, the acidity value was similar to the value determined by [7] and higher than the value determined by [27] in the milk used in churned butter production.

In butters presented to consumption in Adana, the average fat content was detected as $79.5 \%$ and the titration acidity value was detected as $0.16 \%$ in $1 . a \%$ [28]. [29] stated that the fat content in butters presented to consumption in Trabzon is $79.5-87.5 \%$ and the acidity value is $0.22-1.47 \%$ 1.a. [30] detected that the fat content of butters purchased from the markets in Van was between $76-83 \%$.

The amount of fat detected in cream butters is within the range of values determined by [29] and higher than the values determined by [30] and [28] in butter samples. It is thought that factors such as the composition of the used milk, the cream-making method, the fat content of the creams and the butter-processing method are effective in differences between butter samples.

The acidity value detected in cream butter differs from the values of other researchers. Increases and decreases in the amount of dry matter cause a change in the titration acidity of the milk [31]. The fact that the fat-free dry matter elements are transferred to the buttermilk to a large extent during the churning process is one of the factors that cause the low titration acidity of butter.

Fat and protein values of butter samples made from whey are lower than the amount detected by [13] in the butter that they produced from whey. It can be stated that factors such as the fat content of the whey and the butter-processing method play a role in the differences between whey butter samples.

Ten saturated and 7 unsaturated fatty acids were detected in butters. The most common fatty acids are palmitic, stearic, myristic and oleic acid.

The fact that palmitic, stearic and myristic acid are the most common fatty acids found in butter has been reported by other researchers, too [2], [27], [32]. Oleic acid, which is the main unsaturated fatty acid in milk, is used as an energy source and in the reserves of body fat. It is believed that the consumption of monounsaturated fatty acids, such as oleic acid, which is one of the precursors of very long-chain fatty acids used in the structure of brain tissue, particularly in myelin, and relatively neutral in terms of cardiovascular aspect, is useful in reducing low-density lipoprotein (LDL) (bad cholesterol) levels in the blood [33], [34].

$69.56 \%$ of fatty acids detected in cream butter was composed of saturated fatty acids ( $\mathrm{SSFA})(47.86 \%$ palmitic, $17.30 \%$ stearic, $17.29 \%$ myristic acid), $29.00 \%$ was composed of monounsaturated fatty acids ( $\Sigma$ MUFA), $2.12 \%$ was composed of polyunsaturated fatty acids ( $\Sigma$ PUFA).

[35] detected as $66.01 \% \Sigma$ SFA, $25.62 \% \Sigma$ MUFA and 1.47 $\Sigma$ PUFA in butter made from creams obtained from cow's milk.

[30] found the values as $\Sigma$ SFA $61-74 \mathrm{~g} / 100 \mathrm{~g}, \Sigma \mathrm{MUFA}$ $1116-7061 \mathrm{mg} / \mathrm{kg}$ and $\Sigma$ PUFA $40-667 \mathrm{mg} / \mathrm{kg}$ in the butters they collected from the markets in Van.

$67.77 \%$ of fatty acids detected in whey butter was composed of saturated fatty acids ( $\Sigma$ SFA) $(49.48 \%$ palmitic, $17.72 \%$ stearic, $15.97 \%$ myristic acid), $30.33 \%$ was composed of monounsaturated fatty acids ( $\Sigma$ MUFA), $2.07 \%$ was composed of polyunsaturated fatty acids ( $\Sigma$ PUFA). Total saturated fatty acids and polyunsaturated fatty acid values of whey butters were found lower than cream butters, but monounsaturated fatty acid values were found higher.

In butter samples, total short-chain fatty acid amounts in whey butter were detected as $3.59 \%$, medium-chain fatty acid amounts as $18.54 \%$, long-chain fatty acid amounts as $77.04 \%$, very long chain fatty acids $0.86 \%$ and in cream.

Butter: total short-chain fatty acid amounts were detected as $3.61 \%$, medium-chain fatty acid amounts as $20.56 \%$, long-chain fatty acid $73.74 \%$ and very long chain fatty acids amounts as $0.91 \%$ (Table III).

In the study conducted to determine the fatty acids of Trabzon butters; the total short-chain fatty acid levels of the samples were detected as $1.43-2.17 \%$, medium-chain fatty acid levels as $0.09-12.00 \%$, long-chain fatty acids as 0.01 $34.24 \%$ and very long-chain fatty acid $0.02-1.01 \%$ [2].

[30] detected the short-chain fatty acids as 37$4593 \mathrm{mg} / \mathrm{kg}$, medium-chain fatty acids as $348-4499 \mathrm{mg} / \mathrm{kg}$ and long-chain fatty acids as $2027-17470 \mathrm{mg} / \mathrm{kg}$ in the butters presented for consumption in Van.

The short-chain fatty acid rates of whey butter and cream butter samples are higher than the values detected by [2] in Trabzon butter and lower than the values determined by [30] in the butters presented for consumption in Van. The amount of medium-chain and long-chain fatty acids is in the value range detected by [2] in Trabzon butter.

The amounts of palmitic, stearic, oleic acid and the amount of unsaturated fatty acids in whey butter are higher than those of cream butter. It is thought that this difference may be effective in the enzymes of the microorganisms that develop in the cold during the waiting process of the cream becoming active in the later phases and accelerate the lipolysis [36].

The values detected in experimentally produced butter 
samples are higher than the ones detected by [35]. and [30]. Factors such as the composition of raw material milk used in butter production, the fat content of the cream, the buttermaking method and the production period constitute the differences between the results obtained. The amount of long-chain fatty acids in both butter samples is higher than short and medium-chain fatty acids.

The water solubility of fatty acids is related to the number of carbons. As the number of carbon increases, volatility and water solubility decreases and carbon fatty acids of which carbon number is 10 more are insoluble in water [37, 38]. Thus, fatty acids which are soluble in the fatty phase don't segregate with the buttermilk and the concentration of the high molecular fatty acids at a higher level in the fatty phase of the fatty acid compared to short-chain fatty acids is the main cause of the detected increase.

It was found that the short-chain fatty acids rates were lower in the total fatty acids in butters. It is thought that this situation results from the dissolution of nearly all of the butyric acid and partially caproic acid, which are among the fatty acids, in water.

[39] stated that the low rates of short-chain fatty acids in the total fatty acids in the butters presented for sale in Urfa may result from the dissolution of butyric acid and partially the caproic acid in water or vaporizing with water vapor.

The amount of high molecular saturated fatty acids detected in the samples is higher than the sum of both low molecular fatty acids and unsaturated fatty acids. It is thought that the distribution of fatty acids in fat globules is effective in obtaining this result. The high molecular fatty acids exhibit a sequence associated with the membrane of the fat globules. The fact that this fraction is in solid form at room temperature gives the fat globules a certain resistance. Low molecular saturated fatty acids and unsaturated fatty acids found in liquid form at room temperature are located at the center of the fat globulin [36].

$\mathrm{Al}$ [40] states that the ratio of unsaturated fatty acids and short-chain fatty acids in butter obtained from whey separated from Ras and Mozzarella cheese is higher than cream butter. In particular, considering that the linolenic acid ratio increased by more than $50 \%$ in both whey fats provides an advantage to the nutritional values of these fats, as well as the risk of atherosclerosis caused by the consumption of animal fats containing high saturated long chain fatty acid.

In this study, it was determined that the ratio of unsaturated fatty acids in butter made from whey is higher than butter made from milk cream, and the ratio of saturated fatty acids is lower than butter made from milk cream. Our results are in agreement with the results of this researcher.

\section{CONCLUSIONS}

In conclusion, 10 saturated and 7 unsaturated fatty acids were detected in cream and whey butter samples. The most common fatty acids were palmitic, stearic, myristic and oleic acid.

The amount of free fatty acids in dairy products not only has an important effect on the taste and structure of dairy products, but they also have potential effects on nutrition and health. Fatty acid composition of milk may vary due to reasons such as type of the milk, genetic and physiological factors of animals, lactation, season, feed, and geographic location. Therefore, the fatty acid content of butter, like other dairy products, is highly affected by these factors. The concentration of short-chain fatty acids such as butyric, caproic, caprylic and capric acids can have an impact on the flavor properties of butter. The variety of aroma components that affect consumer appreciation is an indication of product quality.

Whey is an important dairy by-product, and about $85 \%$ of the milk used in cheese production is obtained from whey.

Considering the factors such as the high nutritional value of whey in terms of its composition and its disposal without utilization leading to economic loss along with causing environmental pollution, these dairy products should be evaluated in order for dairy production to be profitable, to reduce the cost and to prevent waste. Since the endurance period of skimmed milk powder is longer than that of fatty milk powder, during whey powder production, whey cream can be separated and processed into whey, and the cream separated during the process can be an alternative raw material in butter production.

When the butter made from whey cream and the butter made from cream are compared, not much difference is observed. It can be said that whey butter is an aromatic product because it contains fatty acids which have an important effect on the taste and aroma of milk and dairy products.

Also, we can state that since butter production with whey cream can be less costly than butter production with sweet cream, it can be used as an alternative raw material in butter production.

\section{REFERENCES}

[1] F. Tosun, "Ekzopolisakkarit üreten laktik kültürlerin tereyağı, yayık tereyağı ve kaymağın kalite özellikleri üzerine etkisi”. Erciyes Üniv., Fen Bilim. Enst. Gıda Mühendisliği Anabilim Dalı, Doktora Tezi, Kayseri, Türkiye, 2016.

[2] T. Özcan, A. Akpınar-Beyazıt , L. Yılmaz, K. Çetin and B. Delikanlı, "Evaluation of Fatty Acid Profile of Trabzon Butter" International Journal of Chemical Engineering and Applications, vol. 7, pp. 190193. June 2016.

[3] A. Yetişmeyen, Süt Teknolojisi. Ankara Üniversitesi, Ziraat Fakültesi ders kitab1, yayın no: 1482, Ankara, 1997, sayfa: 200.

[4] M. Demirci, İ. Soysal and A.N. Yüksel, Memeden Mamul Maddeye Süt. Hasad Yayınc1lık. Hayvancılık serisi 1, 1991, sayfa. 103-112.

[5] Turkish Food Codex, Notification No. 2005/19 on butter, milk butter based products and clarified butter, 12 April 2005 [LEXFAOC108244].

[6] H. Yaygın, Tereyağı Üretim Teknikleri. Süt Ürünleri Semineri, 6 May1s 1985, s: 12-26. İstanbul Ticaret Odası, Yay. No: 7, 1985.

[7] A.A. Hayaloğlu, "Malatya yöresinde kremadan ve yoğurttan elde edilen çeşitli tereyağlarının fizikokimyasal mikrobiyolojik ve duyusal nitelikleri üzerine karşılaștırmalı bir araștırma," Cukurova Üniv., Fen Bilim. Enst., Gıda Mühendisliği Anabilim Dalı. Yüksek Lisans tezi. Adana, Türkiye, 1999.

[8] A.H. Dinçoğlu, and M. Ardıç, "Peynir altı suyunun beslenmemizdeki önemi ve kullanım olanakları," Harran Üniversitesi Veteriner Fakültesi Dergisi, vol. 1, pp. 54-60. 2012.

[9] N. Kaptan, Süt Teknolojisi. Ankara Üniversitesi, Ziraat Fakültesi Yayınları: 969, Ankara Üniv. Basımevi, Ankara, 1986.

[10] H. Mete, "Peynir altı suyunun ekmekçilikte değerlendirilmesi ve ekonomik önemi," Tekirdă̆Serbet Muhasebeci Mali Müşavirler Odası Sosyal Bilimler Dergisi, vol. 1, pp.1-10, Eylül 2012.

[11] TUIK, Süt ve Süt Üürnleri Üretim Oranları, http://www.tuik.gov.tr/ VeriBilgi., Erişim Tarihi: 15.07.2019 
[12] A. Kurt and S. Gülümser, "Peynir suyu ve kullanım imkanları," Atatürk Üniversitesi Ziraat Fakültesi Dergisi, vol.18, pp.1-4, 1987

[13] S. Jinjarak, A. Olabi, R., Jimenez-Flores and J.H. Walker, "Sensory, functional, and analytical comparisons of whey butter with other butters," Journal of Dairy Science, vol. 89, pp. 2428-2440, July 2006.

[14] T. İnal and Ö. Ergün, Süt ve Süt Ürünleri Teknolojisi, Panzehir Kitapevi Yayınları, İstanbul, 1990.

[15] P.L.H. McSweeney and M.J. Sousa, "Biochemical pathways for the production of flavour compounds in cheeses during ripening, " A review, Lait vol. 80, pp. 293-324. May-June 2000.

[16] K.N. Kilcawley and D.T. Mannion, Free Fatty Acids Quantification in Dairy Products, World's largest Science, Technology \& Medicine Open Access book publisher. Published by Intech, Chapter 12, pp. 209-219, 2017

[17] F.F. Fox and J.M., Wallace, "Formation of flavour compounds in cheese". Advances in Applied Microbiology,, vol, 45, pp. 17-85, Jan 1997.

[18] Y.F. Collins, P.L.H. McSweeney and M.G. Wilkinson, "Lipolysis and free fatty acid catabolism in cheese," A review of current knowledge. International Dairy Journal, vol.13, pp. 841-866, 2003.

[19] S. Kuzdzal-Savoie, Determination of free fatty acids in milk and milk products. IDF Bulletin. 118, pp. 53-66, 1980.

[20] S. Kamath, A. Wulandewi and H. Deeth, "Relationship between surface tension, free fatty acid concentration and foaming properties of milk," Food Research International, vol. 41, pp. 623-629, July 2008.

[21] Anonymous, TS 1018. Çiğ Süt Standardl. Necatibey cad.Yenişehir Ankara.2002.

[22] Anonymous, TS 1864, Kremada yă̆ miktarı tayini, Necatibey cad. Yenişehir Ankara. 2008.

[23] Anonymous, TS 1331 Tereyağı Standardı,. Necatibey cad.Yenișehir Ankara. 1995.

[24] A. Kurt, S. Çakmakçı and A. Çağlar, Süt ve Mamulleri Muayene Analiz Metotları Rehberi. Atatürk Üniversitesi, Ziraat Fakültesi Yayın No: 257, Erzurum, Türkiye, pp. 124-137, 1993.

[25] AOAC, Official Methods of Analysis: Official Method for Protein Method No. 920.87. Association of Official Analytical Chemists, Washington DC. 1995.

[26] S. Satchithanandam, J. Fritsche and I. Rader, "Extension of AOAC official method 996.01 to the analysis of standard reference material (SRM) 1846 and infant formula," J AOAC Int, vol. 84, pp. 805, 2001.

[27] O. Sağdıç, M. Dönmez and M. Demirci, "Comparison of characteristic and fatty acid profiles of traditional Turkish yayik butters produced from goats', ewes' or cows' milk," Food Control, vol. 15 , pp. 485 - 490, September 2004.

[28] Z. Aykanat, "Adana ilinde tüketime sunulan bazı süt ürünlerinin fiziksel ve kimyasal özellikleri açısından standartlara uygunluğunun araştırılması”, Yüksek Lisans Tezi.Çukurova Üniv., Adana, Türkiye, 1995.

[29] M. Şengül, S. Cakmakcı and M., Unsal, "Determination of some physical and chemical properties of Trabzon butter", in Proc. V.
Symposium on Milk and Milk Products, Tekirdag, May 21-22. 621: 230-243. Türkiye, 1998.

[30] O. Findık and S. Andiç, "Some chemical and microbiological properties of the butter and the butter oil produced from the same raw material," LWT - Food Science ant Technolgy Journal, vol.86, pp 233-239, December 2017.

[31] P. Walstra and R. Jennes, Dairy Chemistry and Physics. Wiley Interscience Publishers, New York. 58 - 197.1984

[32] A.H. Rady and B.M, Badr, "Keeping the quality of cows' butter byirradiation," Grasas y aceites, vol. 54, pp. 410-418. October 2003

[33] S. Yu, J. Derr, T.D., Etherton and P.M. Kris-Etherton, "Plasma cholesterol-predictive equations demonstrate that stearic acid is neutral and monounsaturated fatty acids are hypocholesterolemic,' The American Journal of Clinical Nutrition, vol. 61, pp. 1129-1139, May 1995

[34] S. M. Grundy, "Influence of stearic acid on cholesterol metabolism relative to other long-chain fatty acids.," The American Journal of Clinical Nutrition, vol. 60, pp. 986S-990S, December 1994.

[35] J. Smanalieva, Z. Ozbekova, A. Kulmyrzaev and P. Fischer, "Investigation of fatty acid composition, thermal and rheological behavior of yak, cow and horse fats, “ Manas Journal of Engineering, vol. 7, pp. 24-33, June 2019.

[36] E. Şenel, "Bazı üretim parametrelerinin yoğurttan üretilen yayık tereyağının nitelikleri üzerine etkisi,” Ankara Üniv., Fen Bilim. Enst, Doktora tezi. Ankara, Türkiye, 2006.

[37] M. Kayahan, Lipidler, Gıda Kimyası. Editör İ. Saldamlı, Hacettepe Üniversitesi Yayınları, 107-193. Ankara, 1998.

[38] A.Y. Tamime, R.K. Robinson, Yoghurt Science and Technology. Second Edition. Woodhead Publishing Limited. Cambridge England 1999.

[39] A.F. Atasoy and H., Türkoğlu, "Șanlıurfa'da üretilen ve satıșa sunulan sadeyağların (Urfa Yağı) serbest yağ asitleri bileşiminin belirlenmesi üzerine bir araştırma," Harran Üniversitesi Ziraat Fakültesi Dergisi, vol. 14, pp. 9-12, January 2010.

[40] A. H. Amal, "Fatty acid composition, textural and organoleptic properties of whey butter," Journal of Food and Dairy Sciences, vol. 34, pp. 3081-3094, April 2009.

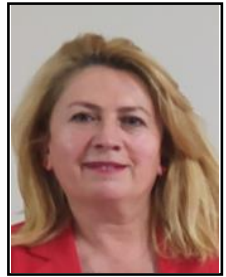

Cetinkaya A. is an asistant professor at the Department of Food Engineering, Kafkas University, Kars, Turkey. More recently, she has worked in the field of fatty acids and flavor compounds of dairy products. Her research interests also include the production and chemistry of different types of cheese, their biochemistry, lactic acid bacteria in dairy products, traditional cheeses and their properties, and packaging materials in cheeses. 